Article

\title{
Encapsulation of a Ru(II) Polypyridyl Complex into Polylactide Nanoparticles for Antimicrobial Photodynamic Therapy
}

\author{
Nancy Soliman ${ }^{1,2}\left(\mathbb{D}\right.$, Vincent Sol $^{3}\left(\mathbb{D}\right.$, Tan-Sothea Ouk ${ }^{3, *(\mathbb{D}}$, Christophe M. Thomas $^{1, * \mathbb{C}}$ \\ and Gilles Gasser ${ }^{2} *$ (D) \\ 1 Institut de Recherche de Chimie Paris, CNRS, Chimie ParisTech, PSL University, 75005 Paris, France; \\ nancy.soliman@chimieparistech.psl.eu \\ 2 Laboratory for Inorganic Chemical Biology, Institute of Chemistry for Life and Health Sciences, CNRS, \\ Chimie ParisTech, PSL University, 75005 Paris, France \\ 3 Laboratoire PEIRENE, Limoges University, EA 7500, 123 Avenue Albert Thomas, 87060 Limoges, France; \\ vincent.sol@unilim.fr \\ * Correspondence: tan-sothea.ouk@unilim.fr (T.-S.O.); christophe.thomas@chimieparistech.psl.eu (C.M.T.); \\ gilles.gasser@chimieparistech.psl.eu (G.G.)
}

Received: 10 August 2020; Accepted: 9 October 2020; Published: 13 October 2020

\begin{abstract}
Antimicrobial photodynamic therapy (aPDT) also known as photodynamic inactivation (PDI) is a promising strategy to eradicate pathogenic microorganisms such as Gram-positive and Gram-negative bacteria. This therapy relies on the use of a molecule called photosensitizer capable of generating, from molecular oxygen, reactive oxygen species including singlet oxygen under light irradiation to induce bacteria inactivation. $\mathrm{Ru}(\mathrm{II})$ polypyridyl complexes can be considered as potential photosensitizers for aPDT/PDI. However, to allow efficient treatment, they must be able to penetrate bacteria. This can be promoted by using nanoparticles. In this work, ruthenium-polylactide (RuPLA) nanoconjugates with different tacticities and molecular weights were prepared from a Ru(II) polypyridyl complex, RuOH. Narrowly-dispersed nanoparticles with high ruthenium loadings (up to $53 \%$ ) and an intensity-average diameter $<300 \mathrm{~nm}$ were obtained by nanoprecipitation, as characterized by dynamic light scattering (DLS). Their phototoxicity effect was evaluated on four bacterial strains (Staphylococcus aureus, Staphylococcus epidermidis, Escherichia coli and Pseudomonas aeruginosa) and compared to the parent compound $\mathbf{R u O H}$. RuOH and the nanoparticles were found to be non-active towards Gram-negative bacterial strains. However, depending on the tacticity and molecular weight of the RuPLA nanoconjugates, differences in photobactericidal activity on Gram-positive bacterial strains have been evidenced whereas $\mathrm{RuOH}$ remained non active.
\end{abstract}

Keywords: antimicrobial photodynamic therapy; nanoparticles; photodynamic inactivation; polylactide; ruthenium complexes

\section{Introduction}

With an increasing number of microorganisms showing resistance to antibiotics, we are now stepping into the "post-antibiotic" era-as World Health Organization (WHO) first reported in 2014 - in which common and minor infections can (once again) be fatal [1]. This major health concern has led to the development of new antimicrobial treatments, including antimicrobial photodynamic therapy (aPDT) [2-4]. aPDT is a two-stage procedure involving the administration of a photosensitizer (PS) followed by local irradiation of light of a specific wavelength. Upon light irradiation, the PS is promoted to an excited state from which it can interact with its biological surroundings to form reactive oxygen species (ROS), including the highly cytotoxic singlet oxygen $\left({ }^{1} \mathrm{O}_{2}\right)$. This technique 
was first introduced in 1900 by Oscar Raab when he reported the toxicity of acridine upon sunlight exposure towards Paramecia, a type of microorganism [5]. Research on aPDT has slowed down since the revolutionary discovery of penicillin in 1928, which marked the beginning of the antibiotic area. However, it is slowly regaining interest among the scientific community to tackle the limitations encountered with currently used antibiotics. One of the limitations is the development of bacterial resistance due to the misuse and overuse of antibiotics. The growing interest in aPDT mainly relies on its multi-target nature involving the rapid and effective action of ROS, which makes it less prone to resistance, unlike conventional antimicrobial treatments [6].

The development of alternative antimicrobial treatment modalities comes with the development of new classes of antimicrobials like metal complexes [7-9]. Among them, Ru(II) complexes, including $\mathrm{Ru}(\mathrm{II})$ polypyridyl complexes, hold great promise to inactivate and eradicate pathogenic microorganisms including bacteria, fungi, and viruses [10-12]. Some mono- and poly-nuclear $\mathrm{Ru}(\mathrm{II})$ complexes have already been reported to effectively reduce the viability of different bacterial strains [13-25]. However, research on the antimicrobial activity of Ru(II) polypyridyl complexes upon light irradiation is still in its infancy. Only a few articles in the field of aPDT reported on the photo-inactivation of microorganisms by these types of complexes [26-29], taking benefits from the large variety of $\mathrm{Ru}(\mathrm{II})$ polypyridyl complexes developed for cancer treatment [30]. These studies highlighted the importance of lipophilicity, charge, and charge separation of molecules on antimicrobial activity.

To allow efficient aPDT, PSs must be able to bind and penetrate microbial cells. Binding and uptake of PS by the microbial cells can be improved by using polymeric nanoparticles (NPs), which not only allow the delivery of photosensitizers to bacteria but also, in some cases, increase the ${ }^{1} \mathrm{O}_{2}$ quantum yield production by preventing the quenching effects that some PSs endure in an aqueous medium. So far, this strategy has only been used with organic photosensitizers [31-34]. There are two ways to prepare NPs for PS delivery: (i) covalent conjugation where a chemical bond is used to attach the PS to a constituent of the nanostructure and (ii) physical encapsulation. Although the physical encapsulation is widely used, it suffers from strong limitations including burst release and poor drug loading which can be overcome using the covalent encapsulation.

In this regard, we hypothesized that $\left[\mathrm{Ru}(\text { bipy })_{2}\right.$-dppz-7-hydroxymethyl] $\left[\mathrm{PF}_{6}\right]_{2}$ (bipy = 2,2'-bipyridine, dppz = dipyrido[3,2-a:2;2',3'-c]phenazine) (RuOH) [35], a previously described $\mathrm{Ru}(\mathrm{II})$ polypyridyl complex, could be a potential antimicrobial agent when associated with an appropriate drug carrier. As already demonstrated by our groups [36], the lipophilicity of this complex can be increased by its conjugation to the end-chain of a hydrophobic polylactide (PLA) via the drug-initiated ring-opening polymerization (ROP) of lactide (LA), resulting in ruthenium-polylactide (Ru-PLA) conjugates that can be formulated into sub-300 nm NPs by nanoprecipitation (Scheme 1). These Ru-PLA nanoconjugates were characterized by superior photophysical properties, including luminescence and enhanced ${ }^{1} \mathrm{O}_{2}$ generation due to a lower amount of quenching effects in aqueous media compared to RuOH alone, and a moderate phototoxicity against cancerous human cervical carcinoma (HeLa) cells. An $\mathrm{IC}_{50}$ as low as $4.4 \mu \mathrm{M}$ and a phototoxicity index (PI) up to 11 were unveiled. These results prompted us to investigate their antimicrobial activity against four bacterial strains, two of which are Gram-positive (Staphylococcus aureus and Staphylococcus epidermidis) and the other two are Gram-negative (Escherichia coli and Pseudomonas aeruginosa) bacteria. To the best of our knowledge, this is the first time that $\mathrm{Ru}(\mathrm{II})$ polypyridyl complexes encapsulated in polymer NPs have been used in aPDT. 


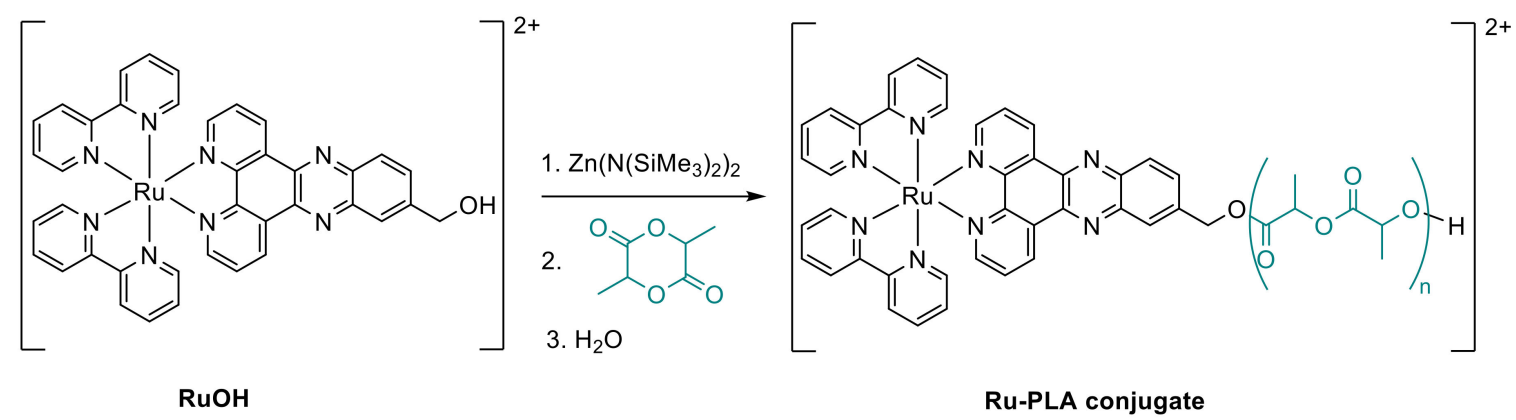

Scheme 1. Synthesis of RuPLA from RuOH.

\section{Materials and Methods}

\subsection{Materials}

The preparation of RuPLA conjugates were carried out under a purified argon atmosphere using Schlenk techniques or a glovebox (Jacomex, Lyon, France) $\left(<1\right.$ ppm $\mathrm{O}_{2},<2$ ppm $\left.\mathrm{H}_{2} \mathrm{O}\right)$ and then formulated into NPs by nanoprecipitation at $20^{\circ} \mathrm{C}$ as previously reported by our groups [36].

\subsection{Instrumentation and Methods}

The nanoparticle intensity-average diameters $D_{\mathrm{z}}$ and the polydispersity index (PdI) were determined by dynamic light scattering (DLS) using a ZetaSizer (Nano ZS, Malvern Instruments, Worcestershire, UK) with a scattering angle of $173^{\circ}$ at a temperature of $25^{\circ} \mathrm{C}$ with an equilibrium time of $120 \mathrm{~s}$. The zeta-potential $(\mathrm{mV})$ was measured at $25^{\circ} \mathrm{C}$ after dilution with $1 \mathrm{mM} \mathrm{NaCl}$ using the Smoluchowski equation.

\subsection{Bacterial Strains and Conditions of Culture}

Gram-positive (Staphylococcus aureus CIP76.25 and Staphylococcus epidermidis CIP109.562) and Gram-negative (P. aeruginosa CIP76110 and E. coli CIP54.8T) bacterial strains were obtained from Collection Institut Pasteur (CIP, Institut Pasteur Paris, France). These strains were cultured in liquid tryptic soy broth (pancreatic casein extract $17 \mathrm{~g} / \mathrm{L}$, soy flour papaic digest $3 \mathrm{~g} / \mathrm{L}$, dextrose $2.5 \mathrm{~g} / \mathrm{L}, \mathrm{NaCl}$ $5 \mathrm{~g} / \mathrm{L}$, and $\mathrm{K}_{2} \mathrm{HPO}_{4} 2.5 \mathrm{~g} / \mathrm{L}$ ) and incubated overnight at $37^{\circ} \mathrm{C}$ under aerobic conditions.

\subsection{Bacteria Photoinactivation}

Fresh solutions of RuOH and NPs were directly dissolved into Phosphate-Buffered Saline $1 \mathrm{X}$ (PBS1X, without $\mathrm{Ca}^{2+}$ and $\mathrm{Mg}^{2+}$ ) at a concentration of $100 \mu \mathrm{M}$. From these mixtures, $50 \mu \mathrm{L}$ of serial dilutions (100 $\mu \mathrm{M}$ down to $78 \mathrm{nM}$ ) were transferred into two 96-well plates (BD Falcon, Le Pont de Claix, France). An amount of $50 \mu \mathrm{L}$ of a bacterial culture at a concentration of $4 \times 106 \mathrm{UFC} / \mathrm{mL}$ was deposited in each well. Bacteria were put in contact with each compound for $4 \mathrm{~h}$ at $37^{\circ} \mathrm{C}$ in the dark. Subsequently, the 96-well plates (Thermo Scientific, Illkirch, France) were irradiated with LED visible light (device built in the lab) $\left(4.83 \mathrm{~mW} / \mathrm{cm}^{2}\right)$ for a total fluence of $25 \mathrm{~J} / \mathrm{cm}^{2}$. Controls consisting of 96-well plates were prepared in the same conditions but kept in the dark. After irradiation, $100 \mu \mathrm{L}$ of two-fold-concentrated culture media were added in each well and the 96-well plates were incubated overnight $37^{\circ} \mathrm{C}$ under aerobic conditions. The lowest concentration of each nanoparticle that prevented bacterial growth was considered as the minimum inhibitory concentration (MIC) of that nanoparticle. Bacterial count was performed after a 10-fold serial dilution of each well where an absence of bacterial growth was observed. Each dilution was spread on tryptic soy agar plates using an automatic plater (easySPIRAL, Interscience, Saint Nom La Bretêche, France). After incubation at $37^{\circ} \mathrm{C}$ for $24 \mathrm{~h}$, colonies were counted to determine total colony-forming units (CFU) per milliliter (CFU/mL). The minimum bactericidal concentration $(\mathrm{MBC})$ corresponds to the concentration of the active compound at which 
$99.99 \%$ of the bacteria have been killed (i.e., 4 log reduction compared to the untreated control). A total of three independent experiments were performed with each strain.

\subsection{Effects of Light Fluence}

To observe the effects of light fluence $\left(\mathrm{J} / \mathrm{cm}^{2}\right)$ on the survival rate of each strain, bacteria $(2 \times 106 \mathrm{UFC} / \mathrm{mL})$ were incubated $4 \mathrm{~h}$ at $37^{\circ} \mathrm{C}$ in the dark with $100 \mu \mathrm{L}$ of the different solutions of NPs at a concentration of $50 \mu \mathrm{M}$. Then, bacteria were collected by centrifugation $(10.000 \mathrm{rpm}, 5 \mathrm{~min})$ and washed twice with PBS (1× without $\mathrm{Ca}^{2+}$ and $\left.\mathrm{Mg}^{2+}\right)$. Washed bacteria were resuspended in PBS, transferred into a 96-well plate and irradiated by white LED $\left(4.83 \mathrm{~mW} / \mathrm{cm}^{2}\right)$. Survival rates, calculated in relation to the initial count of each bacterial culture, were plotted by the function of cumulative fluence $\left(\mathrm{J} / \mathrm{cm}^{2}\right)$. Three independent experiments were performed with each strain.

\subsection{Flow Cytometry}

For each bacterial strain, $108 \mathrm{CFU}$ were put in contact with $500 \mu \mathrm{L}$ of each nanoparticle $(10 \mu \mathrm{M}$ in PBS) for $4 \mathrm{~h}$ at $37^{\circ} \mathrm{C}$ in the dark. Then, bacteria were retrieved by centrifugation and washed with sterile PBS. Bacteria were resuspended in $500 \mu \mathrm{L}$ of $1 \times$ PBS after washing step. Before analysis by flow cytometry, $10 \mu \mathrm{L}$ of propidium iodide (PI, $0.5 \mathrm{mg} / \mathrm{mL}$ ) was added to the bacterial suspension. Fluorescence emissions were analyzed with a BD FACSAria III cell sorter (BD Biosciences, Le Pont de Claix, France). Bacterial cells were excited by two lasers. NPss were excited with a 405-nm violet laser and the fluorescence emitted was detected with a BV650 $(670 / 30 \mathrm{~nm})$ filter. PI was excited with a 561-nm yellow-green laser and the fluorescence emitted was detected with a BV605 (610/20 nm) filter. Overall, 10,000 events were counted.

\section{Results and Discussion}

\subsection{Preparation of $R \mathbf{R} \boldsymbol{P L A}$ Nanoconjugates}

RuOH was conjugated to FDA-approved polylactide via the drug-initiated ROP of LA to give RuPLA conjugates with different microstructures and chain lengths (i.e., 2000, 4000 and $7000 \mathrm{~g} / \mathrm{mol}$ ), as previously reported (Table 1) [36]. These conjugates were prepared either from a racemic mixture of $\mathrm{D}, \mathrm{L}$-lactide or from the enantiopure D-lactide or L-lactide. Polymers derived from D,L-lactide yielded an amorphous polymer as a result of the random sequence of $\mathrm{D}$ and L-units along the polymer backbone, whereas polymers derived from the enantiopure monomers yielded semi-crystalline isotactic polymers PLLA and PDLA with a melting temperature $T_{\mathrm{m}}$ around $140{ }^{\circ} \mathrm{C}$. Mixing two isotactic polylactides of opposite configurations (PLLA and PDLA) at an equimolar ratio allowed the formation of a stereocomplex characterized by superior physical properties, in particular thermal properties, with a $T_{\mathrm{m}} 60^{\circ} \mathrm{C}$ higher than that of the respective homochiral polymers, in accordance with what has already been reported in the literature [37-39]. These conjugates were then formulated into reproducible and narrowly dispersed NPs with an intensity-average diameter Dz lower than $300 \mathrm{~nm}$ and a polydispersity index (PdI) around 0.2. The reproducibility of the preparation with respect to particle size was investigated by analyzing three independent batches (Figures S1-S4). The surface charge of NPs was also investigated by zeta-potential $(\zeta, \mathrm{mV})$ measurements. Depending on the microstructure of the RuPLA nanoconjugates, the zeta potential was different. While stereocomplex NPs (namely, NPs3 and NPs5) possess a zeta potential below $10 \mathrm{mV}$, atactic NPs (namely, NPs1, 2 and 4) have a positive zeta potential ca. $30 \mathrm{mV}$, suggesting that $\mathbf{R u O H}$ might be present on the surface of the atactic NPs.

The ruthenium loading $\% \mathbf{R u O H}$ was determined by ${ }^{1} \mathrm{H}$ NMR spectroscopy and confirmed after formulation by UV-vis spectrophotometry using the absorption peak of $\mathrm{RuOH}$ at $450 \mathrm{~nm}$. 
Table 1. Macromolecular and colloidal characterizations of Ru-PLA nanoconjugates.

\begin{tabular}{|c|c|c|c|c|c|c|c|}
\hline Entry & Tacticity & $\begin{array}{c}M_{\mathrm{n}, \mathrm{NMR}}[\mathrm{a}] \\
(\mathrm{g} / \mathrm{mol})\end{array}$ & $\begin{array}{c}\% \mathrm{RuOH}[\mathrm{b}] \\
\mathbf{w t} \%\end{array}$ & NPs & $\begin{array}{c}D_{\mathrm{z}} \pm \mathrm{SD}[\mathrm{c}] \\
\quad(\mathrm{nm})\end{array}$ & $\mathrm{PdI} \pm \mathrm{SD}[\mathrm{c}]$ & $\zeta(\mathrm{mV})[\mathrm{c}]$ \\
\hline P1 & Atactic & 7000 & 15 & NPs1 & $149.7 \pm 0.451$ & $0.117 \pm 0.005$ & $33.4 \pm 2.14$ \\
\hline P2 & Atactic & 4000 & 25 & NPs2 & $128.1 \pm 0.737$ & $0.171 \pm 0.011$ & $31.2 \pm 2.22$ \\
\hline P3 & Isotactic & 4000 & 25 & NPs3 & & $0.167+0.004$ & $426+0.401$ \\
\hline P4 & Isotactic & 4000 & 25 & NPS3 & $116.2 \pm 0.551$ & & \\
\hline P5 & Atactic & 2000 & 53 & NPs4 & $286.2 \pm 3.10$ & $0.173 \pm 0.011$ & N.D. \\
\hline P6 & Isotactic & 7000 & 15 & NPs5 $5>$ & $1773+155$ & $0183+0.011$ & $109+0231$ \\
\hline P7 & Isotactic & 7000 & 15 & NPss & $17 / .3 \pm 1.35$ & $0.183 \pm 0.011$ & $10.9 \pm 0.231$ \\
\hline
\end{tabular}

[a] $M_{n, N M R}$ were calculated by ${ }^{1} \mathrm{H}$ NMR spectroscopy in $\mathrm{CD}_{3} \mathrm{CN}$. [b] Calculated according to $\left(\mathbf{M}(\mathbf{R u O H}) / M_{n, N M R}\right) \times 100$ with $\mathbf{M}(\mathbf{R u O H})=1015.7 \mathrm{~g} / \mathrm{mol}$. [c] Determined by DLS as an average of three measurements, values given with standard deviation (SD).

\subsection{Biological Evaluation of RuPLA Nanoconjugates}

The photobactericidal activity of RuOH and NPs was established through biological assays against four bacterial strains, two Gram-positive strains (S. aureus and S. epidermidis) and two Gram-negative strains (E. coli, and P. aeruginosa), by determining their minimum inhibitory concentrations (MIC) and minimum bactericidal concentrations (MBC). While MIC assays determine the lowest concentration of an antimicrobial agent that prevents visible growth of a microorganism, MBC assays determine the lowest concentration that reduces the viability of the initial bacterial inoculum by $\geq 99.9 \%$ which represents a three-logarithmic decrease. Each experiment was realized in triplicate and repeated three times.

$\mathrm{RuOH}$ and all NPs were ineffective against both Gram-negative strains at $50 \mu \mathrm{M}$ with or without light irradiation, indicating that their MIC and MBC are higher than $50 \mu \mathrm{M}$.

On Gram-positive strains, RuOH and all NPs were ineffective under dark conditions at $50 \mu \mathrm{M}$. However, after light irradiation with LED visible light $\left(4.83 \mathrm{~mW} / \mathrm{cm}^{2}\right)$ for a total fluence of $25 \mathrm{~J} / \mathrm{cm}^{2}$, NPs1, 3 and 5 showed a photobactericidal activity against S. aureus and S. epidermidis (Table 2). The most active NPs are NPs3 and NPs5, the two stereocomplex ones, with a photobactericidal activity at $12.5 \mu \mathrm{M}$. We can therefore conclude that NPs increase the photobactericidal capacity of RuOH. Indeed, this enhancement is probably related to the increased hydrophobicity rendered possible by the PLA chain and the microstructure of the NPs.

Table 2. Minimum inhibitory concentration (MIC) and minimum bactericidal concentration (MBC) $(\mu \mathrm{M})$ for $\mathbf{R u O H}$ and NPs against $S$. aureus and S. epidermidis.

\begin{tabular}{ccccccccc}
\hline \multirow{2}{*}{ NPs } & \multicolumn{4}{c}{ MIC $(\mu \mathrm{M})$} & \multicolumn{4}{c}{ MBC $(\mu \mathrm{M})$} \\
\cline { 2 - 8 } & \multicolumn{2}{c}{ S. aureus } & \multicolumn{2}{c}{ S. epidermidis } & \multicolumn{2}{c}{ S. aureus } & \multicolumn{2}{c}{ S. epidermidis } \\
\hline & Light & Dark & Light & Dark & Light & Dark & Light & Dark \\
\hline RuOH & $>50$ & $>50$ & $>50$ & $>50$ & $>50$ & $>50$ & $>50$ & $>50$ \\
NPs1 & 25 & $>50$ & 25 & $>50$ & $>50$ & $>50$ & 25 & $>50$ \\
NPs2 & 50 & $>50$ & 50 & $>50$ & $>50$ & $>50$ & 50 & $>50$ \\
NPs3 & 25 & $>50$ & 12.5 & $>50$ & 50 & $>50$ & 12.5 & $>50$ \\
NPs4 & $>50$ & $>50$ & N.D. & N.D. & $>50$ & $>50$ & N.D. & N.D. \\
NPs5 & 12.5 & $>50$ & 12.5 & $>50$ & 25 & $>50$ & 12.5 & $>50$ \\
\hline
\end{tabular}

MIC and MBC values have resulted from 3 independent experiments.

The use of high fluence rates of the exciting light can cause oxygen depletion and PS photobleaching. Therefore, low fluence rate is more clinically relevant. To observe the influence of light dose on the survival rate of bacteria, S. aureus and S. epidermidis were directly put in contact with the most active NPs (NPs 1, 3 and 5) in PBS (Figure 1). After an incubation period of $4 \mathrm{~h}$ in the dark in the different solutions, the washed bacteria were irradiated by the same device used previously. Bacterial concentration and 
survival rate were monitored following the increasing light dose. For each strain, three independent experiments were performed.

S. aureus

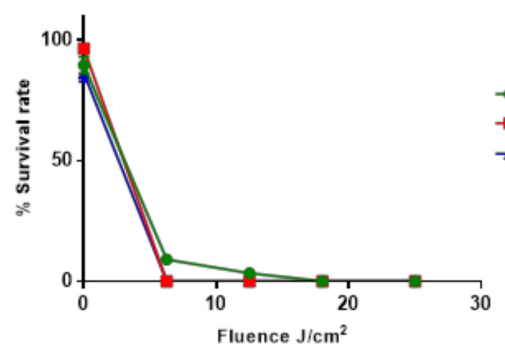

S. epidermidis

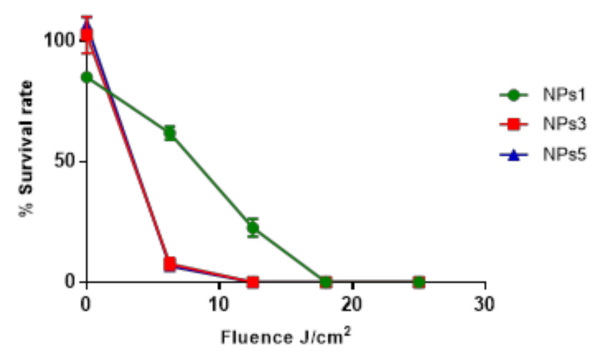

Figure 1. Photodynamic inactivation of S. aureus and S. epidermidis depending on the light dose.

NPs3 and 5 showed the best activity against these two bacterial strains since a low light dose $\left(6.25 \mathrm{~J} / \mathrm{cm}^{2}\right)$ is sufficient to induce a reduction of up to three $\log$ of the survival rate. For NPs 1, a light dose of $18.75 \mathrm{~J} / \mathrm{cm}^{2}$ is necessary to induce a complete eradication of bacterial strains.

To understand more the results observed from the bacteria viability assays, flow cytometry experiments were performed to compare the interaction of NPs with bacteria (Figure 2). The two Gram-positive strains and one Gram-negative strain ( $P$. aeruginosa) were incubated with the solutions of NPs (NPs1, 2, 3 and 5) at $10 \mu \mathrm{M}$. After $4 \mathrm{~h}$ of incubation in the dark at $37^{\circ} \mathrm{C}$, the bacteria were washed with PBS by centrifugation and the washed bacteria were resuspended with $500 \mu \mathrm{L}$ of PBS. Fluorescence emissions were analyzed with a BD FACS Aria III cell sorter. Histograms were used to determine the percentage of labeled bacteria with NPs. These percentages were compared with the percentage obtained with the untreated bacteria used as a reference. NPs1 and NPs2 showed weak to no interaction with bacteria. These results are consistent with the low or lack of photobactericidal activity of NPs1 and NPs2 observed above. Although NPs3 showed a photobactericidal activity, a weak interaction is observed with these NPs. Concerning NPs5, a remarkable fluorescence is obtained after incubation of these NPs with bacteria. This high fluorescence indicates a strong interaction of NPs with bacteria. We can observe a difference between the two types of bacteria. A lower interaction is obtained with the Gram-negative strain. However, it must be pointed out that flow cytometry only gives an idea of possible interaction between NPs and bacteria but does not give information about the uptake. This difference of interaction was highlighted in numerous studies that discuss the fundamental difference in susceptibility to aPDT between Gram-positive and Gram-negative due to the difference of the structure of the bacterial cell walls [40-42]. Gram-positive bacteria possess a thick cell wall $(20-80 \mathrm{~nm})$ of peptidoglycan as outer shell of the cell. In contrast, Gram-negative bacteria have a relatively thin $(<10 \mathrm{~nm})$ layer of cell wall composed of peptidoglycan but harbor an additional outer membrane made of layer of lipopolysaccharide [43]. These differences in the cell envelope confer different properties to the cell. One would have expected NPs1 and NPs2 to have the best interaction with bacteria, and hence photobacterial activity, because of their positive zeta potentials, especially NPs1 which, in addition, is more hydrophobic. Indeed, the presence of a positive zeta potential should favor the electrostatic interaction between the particles and Gram-negative and Gram-positive bacteria whose membranes are negatively charged. However, the microstructure of RuPLA nanoconjugates seems to play an important role in their interaction with bacteria, and hence in their photobactericidal activity. More work needs to be done to have a complete understanding of the role of polymer microstructure on the interaction with bacteria. 


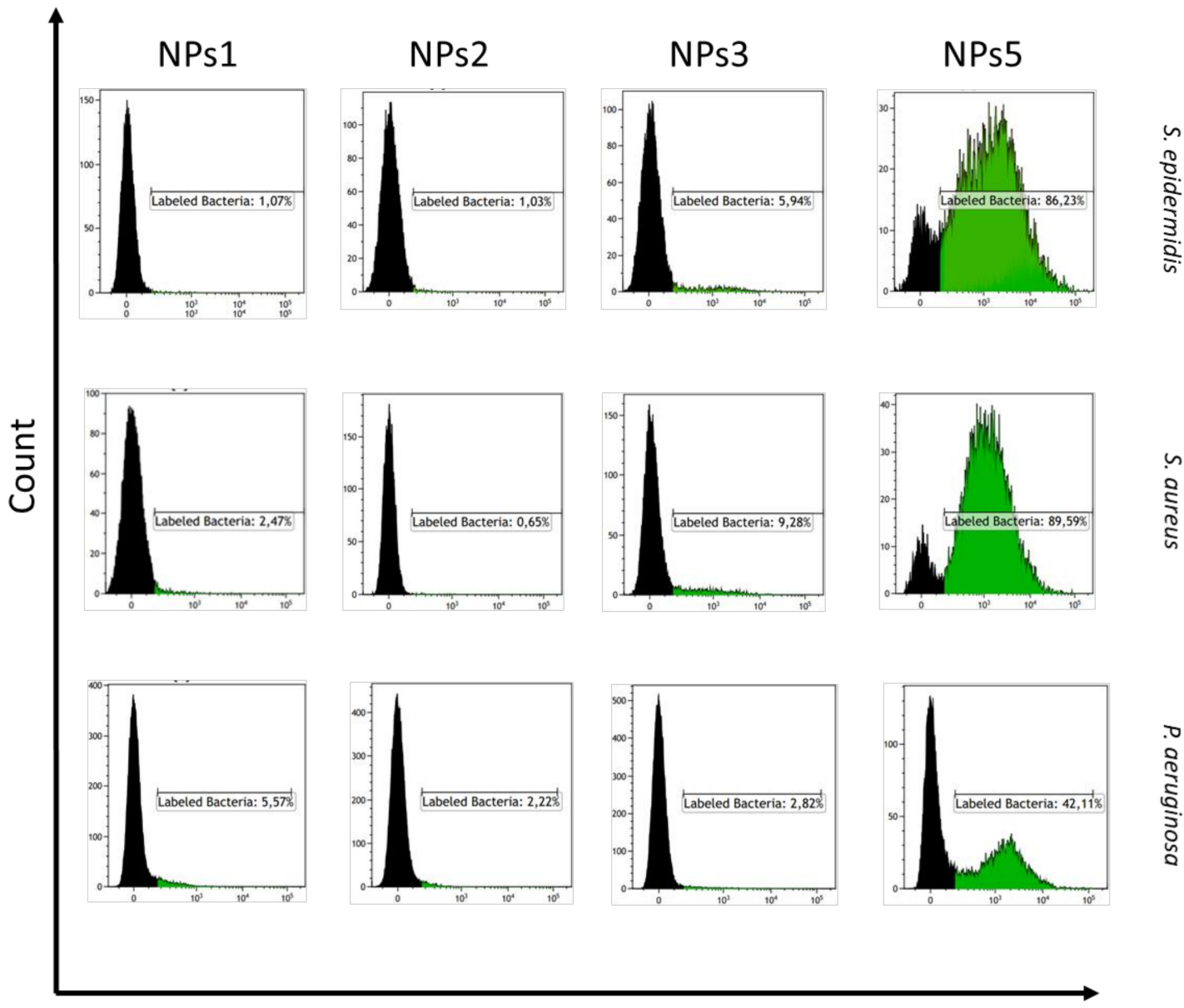

Fluorescence

Figure 2. Flow cytometry analyses. Cytofluorometric profiles representing the distribution of bacterial cells labeled with NPs.

\section{Conclusions}

In this study, we were able to obtain a modest photobactericidal activity on Gram-positive bacterial strains from a ruthenium(II) polypyridyl complex RuOH that could not, in its initial form, inactivate bacterial cells in the dark and under light irradiation. This has been made possible by preparing RuPLA nanoconjugates where $\mathbf{R u O H}$ is conjugated to the chain-end of PLA, an FDA approved biodegradable and biocompatible hydrophobic polymer. Depending on the microstructure and molecular weights of RuPLA nanoconjugates, differences in the photobacterial activity and interaction with bacteria have been evidenced with the best results obtained with the stereocomplex nanoparticles. Even though, modest photobactericidal activity has been observed, these results emphasize the potential of $\mathrm{Ru}(\mathrm{II})$ polypyridyl complexes if coupled with appropriate nanomaterials for aPDT. We are currently investigating the encapsulation of other $\mathrm{Ru}(\mathrm{II})$ complexes that absorb at higher wavelengths. These results will be published in due course.

Supplementary Materials: The following are available online at http://www.mdpi.com/1999-4923/12/10/961/s1, Figure S1: Reproducibility of the size distribution of NPs1 by preparation of three independent batches, each measured three times, Figure S2: Reproducibility of the size distribution of NPs2 by preparation of three independent batches, each measured three times, Figure S3: Reproducibility of the size distribution of NPs3 by preparation of three independent batches, each measured three times, Figure S4: Reproducibility of the size distribution of NPs5 by preparation of three independent batches, each measured three times.

Author Contributions: Conceptualization, C.M.T. and G.G.; Validation, N.S., T.-S.O., C.M.T. and G.G.; Formal Analysis, N.S. and T.-S.O.; Investigation, N.S. and T.-S.O.; Resources, V.S., C.M.T. and G.G. Writing-Original Draft Preparation, N.S. and T.-S.O.; Writing-Review \& Editing, V.S., C.M.T. and G.G.; Visualization, C.M.T. and G.G.; 
Supervision, V.S., C.M.T. and G.G.; Project Administration, C.M.T. and G.G.; Funding Acquisition, C.M.T. and G.G. All authors have read and agreed to the published version of the manuscript.

Funding: This work was financially supported by an ERC Consolidator Grant PhotoMedMet to G.G. (GA 681679) and has received support under the program Investissements d'Avenir launched by the French Government and implemented by the ANR with the reference ANR-10-IDEX-0001-02 PSL (G.G.). N.S gratefully acknowledges financial support from Cancéropôle Île-de-France for her $\mathrm{PhD}$ scholarship. C.M.T. is grateful to the Institut Universitaire de France.

Acknowledgments: The authors would like to thank Purac for a generous loan of D,L-lactide. The authors thank Catherine Ouk from the Biscem core facility from University of Limoges for FACS analysis.

Conflicts of Interest: The authors declare no conflict of interest.

\section{References}

1. World Health Organization. Antimicrobial Resistance: Global Report on Surveillance; World Health Organization: Geneva, Switzerland, 2014.

2. Wainwright, M. Photodynamic antimicrobial chemotherapy (PACT). J. Antimicrob. Chemother. 1998, 42, 13-28. [CrossRef]

3. Hamblin, M.R.; Hasan, T. Photodynamic therapy: A new antimicrobial approach to infectious disease? Photochem. Photobiol. Sci. 2004, 3, 436-450. [CrossRef]

4. Hamblin, M.R. Antimicrobial photodynamic inactivation: A bright new technique to kill resistant microbes. Curr. Opin. Microbiol. 2016, 33, 67-73. [CrossRef] [PubMed]

5. Rabb, O. Uber die wirkung Fluorescirender Stoffe auf Infusorien. Z. Biol. 1900, 39, 524-546.

6. Cieplik, F.; Deng, D.; Crielaard, W.; Buchalla, W.; Hellwig, E.; Al-Ahmad, A.; Maisch, T. Antimicrobial photodynamic therapy-What we know and what we don't. Crit. Rev. Microbiol. 2018, 44, 571-589. [CrossRef] [PubMed]

7. Frei, A.; Zuegg, J.; Elliott, A.G.; Baker, M.; Braese, S.; Brown, C.; Chen, F.; Dowson, C.G.; Dujardin, G.; Jung, N.; et al. Metal complexes as a promising source for new antibiotics. Chem. Sci. 2020, 11, 2627-2639. [CrossRef]

8. Frei, A. Metal Complexes, an Untapped Source of Antibiotic Potential? Antibiotics 2020, 9, 90. [CrossRef]

9. İşci, Ü.; Beyreis, M.; Tortik, N.; Topal, S.Z.; Glueck, M.; Ahsen, V.; Dumoulin, F.; Kiesslich, T.; Plaetzer, K. Methylsulfonyl Zn phthalocyanine: A polyvalent and powerful hydrophobic photosensitizer with a wide spectrum of photodynamic applications. Photodiagnosis Photodyn. Ther. 2016, 13, 40-47. [CrossRef]

10. Li, F.; Collins, J.G.; Keene, F.R. Ruthenium complexes as antimicrobial agents. Chem. Soc. Rev. 2015, 44, 2529-2542. [CrossRef]

11. Southam, H.M.; Butler, J.A.; Chapman, J.A.; Poole, R.K. The Microbiology of Ruthenium Complexes. Adv. Microb. Physiol. 2017, 71, 1-96.

12. Golbaghi, G.; Groleau, M.-C.; de los Santos, Y.L.; Doucet, N.; Déziel, E.; Castonguay, A. Cationic Ru ${ }^{\mathrm{II}}$ Cyclopentadienyl Complexes with Antifungal Activity against Several Candida Species. ChemBioChem 2020. [CrossRef] [PubMed]

13. Dwyer, F.P.; Gyarfas, E.C.; Rogers, W.P.; Koch, J.H. Biological Activity of Complex Ions. Nature 1952, 170, 190-191. [CrossRef] [PubMed]

14. Dwyer, F.P.; Reid, I.K.; Shulman, A.; Laycock, G.M.; Dixson, S. The biological actions of 1,10-phenanthroline and 2,2'-bipyridine hydrochlorides, quaternary salts and metal chelates and related compounds. 1. Bacteriostatic action on selected gram-positive, gram-negative and acid-fast bacteria. Aust. J. Exp. Biol. Med. Sci. 1969, 47, 203-218. [CrossRef] [PubMed]

15. Bolhuis, A.; Hand, L.; Marshall, J.E.; Richards, A.D.; Rodger, A.; Aldrich-Wright, J. Antimicrobial activity of ruthenium-based intercalators. Eur. J. Pharm. Sci. 2011, 42, 313-317. [CrossRef] [PubMed]

16. Li, F.; Mulyana, Y.; Feterl, M.; Warner, J.M.; Collins, J.G.; Keene, F.R. The antimicrobial activity of inert oligonuclear polypyridylruthenium(II) complexes against pathogenic bacteria, including MRSA. Dalton Trans. 2011, 40, 5032-5038. [CrossRef] [PubMed] 
17. Weber, D.K.; Sani, M.-A.; Downton, M.T.; Separovic, F.; Keene, F.R.; Collins, J.G. Membrane Insertion of a Dinuclear Polypyridylruthenium(II) Complex Revealed by Solid-State NMR and Molecular Dynamics Simulation: Implications for Selective Antibacterial Activity. J. Am. Chem. Soc. 2016, 138, 15267-15277. [CrossRef] [PubMed]

18. Li, F.; Harry, E.J.; Bottomley, A.L.; Edstein, M.D.; Birrell, G.W.; Woodward, C.E.; Keene, F.R.; Collins, J.G. Dinuclear ruthenium(II) antimicrobial agents that selectively target polysomes in vivo. Chem. Sci. 2013, 5, 685-693. [CrossRef]

19. Lam, P.-L.; Lu, G.-L.; Hon, K.-M.; Lee, K.-W.; Ho, C.-L.; Wang, X.; Tang, J.C.-O.; Lam, K.-H.; Wong, R.S.-M.; Kok, S.H.-L.; et al. Development of ruthenium(II) complexes as topical antibiotics against methicillin resistant Staphylococcus aureus. Dalton Trans. 2014, 43, 3949-3957. [CrossRef]

20. Gorle, A.K.; Feterl, M.; Warner, J.M.; Wallace, L.; Keene, F.R.; Collins, J.G. Tri- and tetra-nuclear polypyridyl ruthenium(ii) complexes as antimicrobial agents. Dalton Trans. 2014, 43, 16713-16725. [CrossRef]

21. Gorle, A.K.; Feterl, M.; Warner, J.M.; Primrose, S.; Constantinoiu, C.C.; Keene, F.R.; Collins, J.G. Mononuclear Polypyridylruthenium(II) Complexes with High Membrane Permeability in Gram-Negative Bacteria-in particular Pseudomonas aeruginosa. Chem. Eur. J. 2015, 21, 10472-10481. [CrossRef]

22. Kumar, S.V.; Scottwell, S.Ø.; Waugh, E.; McAdam, C.J.; Hanton, L.R.; Brooks, H.J.L.; Crowley, J.D. Antimicrobial Properties of Tris(homoleptic) Ruthenium(II) 2-Pyridyl-1,2,3-triazole "Click" Complexes against Pathogenic Bacteria, Including Methicillin-Resistant Staphylococcus aureus (MRSA). Inorg. Chem. 2016, 55, 9767-9777. [CrossRef] [PubMed]

23. Mårtensson, A.K.F.; Bergentall, M.; Tremaroli, V.; Lincoln, P. Diastereomeric bactericidal effect of $\mathrm{Ru}$ (phenanthroline) ${ }_{2}$ dipyridophenazine. Chirality 2016, 28, 713-720. [CrossRef] [PubMed]

24. Smitten, K.L.; Southam, H.M.; de la Serna, J.B.; Gill, M.R.; Jarman, P.J.; Smythe, C.G.W.; Poole, R.K.; Thomas, J.A. Using Nanoscopy To Probe the Biological Activity of Antimicrobial Leads That Display Potent Activity against Pathogenic, Multidrug Resistant, Gram-Negative Bacteria. ACS Nano 2019, 13, 5133-5146. [CrossRef] [PubMed]

25. Smitten, K.L.; Fairbanks, S.D.; Robertson, C.C.; de la Serna, J.B.; Foster, S.J.; Thomas, J.A. Ruthenium based antimicrobial theranostics - using nanoscopy to identify therapeutic targets and resistance mechanisms in Staphylococcus aureus. Chem. Sci. 2020, 11, 70-79. [CrossRef] [PubMed]

26. Donnelly, R.F.; Fletcher, N.C.; McCague, P.J.; Donnelly, J.; McCarron, P.A.; Tunney, M.M. Design, Synthesis and Photodynamic Antimicrobial Activity of Ruthenium Trischelate Diimine Complexes. Lett. Drug Des. Discov. 2007, 4, 175-179. [CrossRef]

27. Lei, W.; Zhou, Q.; Jiang, G.; Zhang, B.; Wang, X. Photodynamic inactivation of Escherichia coli by Ru(II) complexes. Photochem. Photobiol. Sci. 2011, 10, 887-890. [CrossRef]

28. Arenas, Y.; Monro, S.; Shi, G.; Mandel, A.; McFarland, S.; Lilge, L. Photodynamic inactivation of Staphylococcus aureus and methicillin-resistant Staphylococcus aureus with $\mathrm{Ru}(\mathrm{II})$-based type I/type II photosensitizers. Photodiagn. Photodyn. Therapy 2013, 10, 615-625. [CrossRef]

29. Frei, A.; Rubbiani, R.; Tubafard, S.; Blacque, O.; Anstaett, P.; Felgenträger, A.; Maisch, T.; Spiccia, L.; Gasser, G. Synthesis, Characterization, and Biological Evaluation of New Ru(II) Polypyridyl Photosensitizers for Photodynamic Therapy. J. Med. Chem. 2014, 57, 7280-7292. [CrossRef]

30. Le Gall, T.; Lemercier, G.; Chevreux, S.; Tücking, K.-S.; Ravel, J.; Thétiot, F.; Jonas, U.; Schönherr, H.; Montier, T. Ruthenium(II) Polypyridyl Complexes as Photosensitizers for Antibacterial Photodynamic Therapy: A Structure-Activity Study on Clinical Bacterial Strains. ChemMedChem 2018, 13, 2229-2239. [CrossRef]

31. Liu, J.; Zhang, C.; Rees, T.W.; Ke, L.; Ji, L.; Chao, H. Harnessing ruthenium(II) as photodynamic agents: Encouraging advances in cancer therapy. Coord. Chem. Rev. 2018, 363, 17-28. [CrossRef]

32. Yin, R.; Agrawal, T.; Khan, U.; Gupta, G.K.; Rai, V.; Huang, Y.-Y.; Hamblin, M.R. Antimicrobial photodynamic inactivation in nanomedicine: Small light strides against bad bugs. Nanomedicine 2015, 10, 2379-2404. [CrossRef] [PubMed]

33. Perni, S.; Prokopovich, P.; Pratten, J.; Parkin, I.P.; Wilson, M. Nanoparticles: Their potential use in antibacterial photodynamic therapy. Photochem. Photobiol. Sci. 2011, 10, 712-720. [CrossRef] [PubMed]

34. Maldonado-Carmona, N.; Ouk, T.-S.; Calvete, M.J.F.; Pereira, M.M.; Villandier, N.; Leroy-Lhez, S. Conjugating biomaterials with photosensitizers: Advances and perspectives for photodynamic antimicrobial chemotherapy. Photochem. Photobiol. Sci. 2020, 19, 445-461. [CrossRef] [PubMed] 
35. Mari, C.; Pierroz, V.; Rubbiani, R.; Patra, M.; Hess, J.; Spingler, B.; Oehninger, L.; Schur, J.; Ott, I.; Salassa, L.; et al. DNA intercalating $\mathrm{Ru}(\mathrm{II})$ polypyridyl complexes as effective photosensitizers in photodynamic therapy. Chem. Eur. J. 2014, 20, 14421-14436. [CrossRef]

36. Soliman, N.; McKenzie, L.K.; Karges, J.; Bertrand, E.; Tharaud, M.; Jakubaszek, M.; Guérineau, V.; Goud, B.; Hollenstein, M.; Gasser, G.; et al. Ruthenium-initiated polymerization of lactide: A route to remarkable cellular uptake for photodynamic therapy of cancer. Chem. Sci. 2020, 11, 2657-2663. [CrossRef]

37. Ikada, Y.; Jamshidi, K.; Tsuji, H.; Hyon, S.H. Stereocomplex formation between enantiomeric poly(lactides). Macromolecules 1987, 20, 904-906. [CrossRef]

38. Tsuji, H. Poly(lactide) Stereocomplexes: Formation, Structure, Properties, Degradation, and Applications. Macromol. Biosci. 2005, 5, 569-597. [CrossRef]

39. Marin, P.; Tschan, M.J.-L.; Isnard, F.; Robert, C.; Haquette, P.; Trivelli, X.; Chamoreau, L.-M.; Guérineau, V.; del Rosal, I.; Maron, L.; et al. Polymerization of rac-Lactide Using Achiral Iron Complexes: Access to Thermally Stable Stereocomplexes. Angew. Chem. Int. Ed. 2019, 58, 12585-12589. [CrossRef]

40. Pereira, M.A.; Faustino, M.A.F.; Tome, J.P.C.; Neves, M.G.P.M.S.; Tomé, A.C.; Cavaleiro, J.A.S.; Cunha, A.; Almeida, A. Influence of external bacterial structures on the efficiency of photodynamic inactivation by a cationic porphyrin. Photochem. Photobiol. Sci. 2014, 13, 680-690. [CrossRef]

41. Malik, Z.; Hanania, J.; Nitzan, Y. New trends in photobiology bactericidal effects of photoactivated porphyrins-An alternative approach to antimicrobial drugs. J. Photochem. Photobiol. B 1990, 5, 281-293. [CrossRef]

42. Minnock, A.; Vernon, D.I.; Schofield, J.; Griffiths, J.; Parish, J.H.; Brown, S.T. Photoinactivation of bacteria. Use of a cationic water-soluble zinc phthalocyanine to photoinactivate both Gram-negative and Gram-positive bacteria. J. Photochem. Photobiol. B 1996, 32, 159-164. [CrossRef]

43. Salton, M.R.J.; Kim, K.-S. Chapter 2 Structure. In Medical Microbiology, 4th ed.; Baron, S., Ed.; University of Texas Medical Branch at Galveston: Galveston, TX, USA, 1996.

(C) 2020 by the authors. Licensee MDPI, Basel, Switzerland. This article is an open access article distributed under the terms and conditions of the Creative Commons Attribution (CC BY) license (http://creativecommons.org/licenses/by/4.0/). 